\title{
Effect of Oyster mushroom in Paracetamol Induced Toxicity of Liver in Wistar albino Rats
}

\author{
Afroza Khanam Sumy ${ }^{1}$, Nasim Jahan ${ }^{2}$, Nayma Sultana ${ }^{3}$, Abdul Mannan Sikder ${ }^{4}$ \\ Received: November 9, 2013 Accepted: February 18, 2014
}

\begin{abstract}
Backgroud: Liver is an important metabolic organ. It has wide range of functions including detoxification, storage of glycogen, vitamins $A, D$ and $B_{12}$, production of several coagulation factors, growth factors such as insulin-like growth factor-1 (IGF-1), angiotensinogen, and biochemicals necessary for digestion (bile). Its damage occurs due to its multidimensional functions, various xenobiotics and oxidative stress leading to distortion of all of its functions. Oyster mushroom which is excellently edible and nutritious has got free radical scavenging activity, and so may be considered as a hepatoprotective agent. Objective: To observe the hepatoprotective effect of Oyster mushroom (Pleurotus florida) against paracetamol induced liver damage in Wistar albino rats. Materials and Methods: This experimental study was carried out in the Department of Physiology, Sir Salimullah Medical College (SSMC), Dhaka from $1^{\text {st }}$ July 2009 to $30^{\text {th }}$ June 2010. Thirty four Wistar albino rats, aged 90 to 120 days, weighing between 150 to 210 grams were used for the study. After acclimatization for 14 days, they were divided into two groups - control group (Group A) and experimental group (Group B, mushroom-pretreated and paracetamol-treated group). Control group was again subdivided into Group $A_{1}$ (baseline control group) and Group $A_{2}$ (paracetamol-treated control group). Animals of all groups received basal diet for 30 consecutive days. In addition, Group $A_{1}$ rats received propylene glycol $(2 \mathrm{~mL} / \mathrm{kg}$ body weight orally) only on $30^{\text {th }}$ day, Group $A_{2}$ rats received single dose of paracetamol suspension $\left(750 \mathrm{mg} / \mathrm{kg}\right.$ body weight orally) only on $30^{\text {th }}$ day and Group B rats received mushroom extract (200 $\mathrm{mg} / \mathrm{kg}$ body weight orally) for 30 consecutive days and paracetamol suspension (750 mg/kg body weight orally) only on $30^{\text {th }}$ day. All the animals were sacrificed on $31^{\text {st }}$ day. Then liver specimens were collected. Histology of liver was done by using standard laboratory procedure. Statistical analysis was done by one way ANOVA test by using SPSS version 15.0. Result: In this study, histological examination of liver reveals abnormal histological findings in $100 \%$ of rats in paracetamol-treated group (Group $A_{2}$ ), almost normal structure in $80 \%$ of rats and mild histological changes in 20\% rats in mushroom-pretreated and paracetamol-treated group (Group B). Conclusion: The present study reveals the hepatoprotective effect of Oyster mushroom (Pleurotus florida) against paracetamol induced liver damage in Wistar albino rats.
\end{abstract}

Key words: Hepatoprotective; Oyster mushroom; Wistar albino rats

J Enam Med Col 2014; 4(3): 161-167

\section{Introduction}

The liver is the central organ of metabolism. It has great capacity to detoxify toxic substances and synthesize useful products. ${ }^{1}$ It is continuously exposed to varieties of toxic agents like drugs, chemicals, microbiological and viral agents that may interfere with hepatic function and may cause hepatic damage. ${ }^{2}$

1. Assistant Professor, Department of Physiology, Enam Medical College, Savar, Dhaka

2. Professor, Department of Physiology, Sir Salimullah Medical College, Mitford, Dhaka

3. Associate Professor, Department of Physiology, Sir Salimullah Medical College, Mitford, Dhaka

4. Professor, Department of Pathology, Enam Medical College, Savar, Dhaka

Correspondence Afroza Khanam Sumy, Email: afrozakhanam58@yahoo.com 
Paracetamol is an antipyretic and analgesic drug which is widely used to cure fever, headache and other pains and is readily available without prescription. When taken in at toxic dose, it may cause hepatotoxicity by overproduction of reactive oxygen species (ROS) such as superoxide radicals, hydrogen radicals and hydroxyl radicals during the formation of $N$-acetyl $p$ benzoquinoneimine (NAPQI) by cytochrome p450.3,4 Excess levels of ROS can attack biological molecules such as DNA, protein, phospholipids, which leads to lipid peroxidation and depletion of antioxidant enzymes such as superoxide dismutase (SOD), catalase (CAT), and glutathione peroxidase $\left.\left(\mathrm{GP}_{\mathrm{x}}\right)\right)^{5,6}$

Damage to the liver by hepatotoxic agents is of grave consequence as chronic liver injury leads to fibrosis, end stage cirrhosis and hepatocellular carcinoma. As a result there is increasing need to search of an agent which could protect the liver from such damage. Mushrooms have been used in folk medicine throughout the ancient time. Now-a-days, mushrooms are widely used as a nice vegetable. ${ }^{7}$

Mushrooms are a good source of vitamins and minerals and are preferred in many countries because of its special flavor and aroma. ${ }^{8}$ Oyster mushroom (Pleurotus ostreatus) can suppress damage of the liver by its hepatoprotective effect. 9,10

Histological architecture of the liver of toxic animals revealed extensive damage, characterized by the disruption of the normal structure of the hepatocyte, damaged cell membranes, degenerated nuclei, disintegrated central vein and damaged hepatic sinusoids. ${ }^{9,11}$ Use of mushroom extract may protect the liver from damage. $9,12,13$

Antioxidant activity or the inhibition of the generation of free radicals is important in providing protection against hepatic damage. In absence of reliable liver protective drugs in modern medicine, Ayurveda recommended some medicinal preparations for the treatment of liver disorder. Some researchers showed that some mushrooms such as Lentinus edodes, Grifola frondosa and Tricholoma lobayense have hepatoprotective activity. ${ }^{14}$ But in Bangladesh, no study has been done yet to evaluate the hepatoprotective effect of mushroom. Oyster mushroom has highly nutritive and medicinal value, is cultivated and harvested in Bangladesh all over the year. It is reasonably cheap, available and relatively safe in comparison to other mushrooms. Therefore, the present study was designed to observe the hepatoprotective effect of Oyster mushroom (Pleurotus florida) in experimental animals after inducing hepatotoxicity by paracetamol. The findings of this study may be helpful to make this mushroom acceptable among the people as a source of functional food for the prevention of liver diseases.

\section{Materials and Methods}

This experimental study was conducted during July 2009 to June 2010 in the department of Physiology, Sir Salimullah Medical College (SSMC), Mitford, Dhaka. A total number of 34 apparently healthy Wistar albino male rats, weighing 150 to 210 grams, aged 90 to 120 days were used. The animals were purchased from the animal house of Bangladesh Council of Scientific and Industrial Research (BCSIR), Dhaka. Ethical permission was taken from the Institutional Ethical Committee (IEC) of SSMC, Dhaka. Prior to conducting the study the animals had been acclimatized for 14 days under 12-hour dark-light cycles. During this period they had free access to food and water ad libitum. After 14 days of acclimatization, body weights of all rats were measured (initial body weight [IBW]).

After acclimatization for 14 days, all animals were divided into two groups - control group (Group A) and mushroom-pretreated and paracetamol-treated group (Group B). Control group was again subdivided into Group $A_{1}$ (baseline control group) and Group $A_{2}$ (paracetamol-treated control group). Group $A_{1}$ consisted of 10 rats, Group $\mathrm{A}_{2}$ consisted of 14 rats and Group B consisted of 10 rats. Animals of all groups received basal diet for 30 consecutive days. In addition, Group $\mathrm{A}_{1}$ rats received propylene glycol $(2 \mathrm{~mL} / \mathrm{kg}$ body weight orally) only on the $30^{\text {th }}$ day; Group $A_{2}$ rats received single dose of paracetamol suspension $(750$ $\mathrm{mg} / \mathrm{kg}$ body weight orally) only on the $30^{\text {th }}$ day. ${ }^{15}$ Group B rats received mushroom extract $(200 \mathrm{mg} / \mathrm{kg}$ body weight orally) for 30 consecutive days and paracetamol suspension $(750 \mathrm{mg} / \mathrm{kg}$ body weight orally) only on the $30^{\text {th }}$ day. ${ }^{15}$ During the study period, one rat of paracetamol-treated control group died. It might be due to toxic effect of paracetamol. On the $31^{\text {st }}$ day final body weights of all rats (FBW) were measured and then the rats were sacrificed. Then liver samples were collected. After washing in ice-cold saline these were preserved in $10 \%$ formalin for subsequent histological processing which was done by using 
standard laboratory procedure in the department of Pathology of SSMC.

Statistical analysis was done by one way ANOVA, Fisher's exact test and Bonferroni test by using SPSS version 15.0.

\section{Preparation of paracetamol solution}

$1 \mathrm{~g}$ of paracetamol (active ingredient) was dissolved in $9 \mathrm{~mL}$ of propylene glycol. After thorough mixture a homogeneous solution was obtained, giving strength of $111.11 \mathrm{mg}$ of paracetamol per $\mathrm{mL}$ of solution. ${ }^{16}$

\section{Preparation of mushroom extract}

Oyster mushroom was collected from National Mushroom Development and Extension Center (NMDEC), Savar, Dhaka. Fresh mushroom was dried in the sun and finally in the oven and then crushed into powder with a mechanical grinder. Mushroom powder was extracted with ethanol, filtered and evaporated to obtain mushroom extract. $^{9}$

\section{Results}

Table I shows the initial and final body weight of rats and percentage of change of body weight in different groups. The mean ( \pm SD) of body weight of rats were $182.80 \pm 19.57,183.38 \pm 14.13$ and $186.60 \pm 10.11 \mathrm{~g}$ on day 1 whereas $227.10 \pm 19.31$, $223.85 \pm 14.52$ and $216.70 \pm 14.47 \mathrm{~g}$ on day 31 in $A_{1}, A_{2}$ and $B$ groups respectively. Initial body weights of groups $A_{1}, A_{2}$ and $B$ were almost similar and showed no statistically significant difference of these values between groups $A_{1}$ vs $\mathrm{A}_{2}(\mathrm{p}=0.999), \mathrm{A}_{1}$ vs $\mathrm{B}(\mathrm{p}=0.999)$ and $\mathrm{A}_{2}$ vs $\mathrm{B}$ $(p=0.999)$. Final body weights of groups $A_{1}, A_{2}$ and $\mathrm{B}$ were also almost similar and showed no statistically significant difference between groups.

Mean $( \pm \mathrm{SD})$ of percentage of changes in body weight from final to initial weight were $24.69 \pm 7.65,22.27 \pm 5.41$ and $16.21 \pm 6.59 \%$ in groups $A_{1}, A_{2}$ and $B$ respectively. Percentage of change in body weight was significantly $(\mathrm{p}=0.020)$ lower in Group B compared to that of Group $A_{1}$ whereas the percentage of change in body weight was nonsignificant between Group $A_{1}$ and Group $A_{2}$ and Group $A_{2}$ and Group B.
Table I: Initial and final body weight of rats and percentage of change of body weight in different groups $(n=33)$

\begin{tabular}{|l|c|c|c|}
\hline \multirow{2}{*}{ Groups } & \multicolumn{2}{|c|}{ Body weight $(\mathrm{g})$} & $\begin{array}{c}\% \text { of change from } \\
\text { initial (I) weight } \\
\text { to final (F) weight } \\
{[(\mathrm{F}-\mathrm{I}) / \mathrm{I} \times 100]}\end{array}$ \\
\hline & $\begin{array}{c}\text { Initial } \\
\text { (day 1) }\end{array}$ & $\begin{array}{c}\text { Final } \\
\text { (day 31) }\end{array}$ & \\
\hline Group A1 & $182.80 \pm 19.57$ & $227.10 \pm 19.31$ & $24.69 \pm 7.65$ \\
$(\mathrm{n}=10)$ & $(152-210)$ & $(198-257)$ & $(17.49-41.03)$ \\
\hline Group A2 & $183.38 \pm 14.13$ & $223.85 \pm 14.52$ & $22.27 \pm 5.41$ \\
\hline n=13) & $(160-209)$ & $(201-244)$ & $(13.47-31.84)$ \\
\hline $\begin{array}{l}\text { Group B } \\
\text { (n=10) }\end{array}$ & $186.60 \pm 10.11$ & $216.70 \pm 14.47$ & $16.21 \pm 6.59 *$ \\
\hline
\end{tabular}

Results are expressed as mean \pm SD. Statistical analysis was done by ANOVA test and then by Bonferroni test to compare between two groups. Figures in parentheses indicate ranges. ${ }^{*} \mathrm{p}=0.020\left(\mathrm{~A}_{1}\right.$ vs $\left.\mathrm{B}\right)$

Group $\mathrm{A}_{1}$, baseline control group; Group $\mathrm{A}_{2}$, Paracetamol-treated control group; Group B, Mushroom-pretreated and paracetamoltreated group

Table II shows the liver weight in different groups of rats and also comparison between groups. The mean $( \pm \mathrm{SD})$ of liver weights of rats were $3.57 \oplus .40,4.22 \oplus .55$ and $3.88 \pm 0.42 \mathrm{~g}$ in groups $A_{1}, A_{2}$ and $B$ respectively. The liver weight was higher in group $\mathrm{A}_{2}$ when compared to that of group $\mathrm{A}_{1}$ and $\mathrm{B}$; though it was statistically significant $(p<0.01)$ between groups $A_{1}$ vs $A_{2}$, but non-significant between groups $A_{2}$ vs B. Again, liver weight of group $B$ was higher than that of group $\mathrm{A}_{1}$, but the difference was non-significant.

Table II: Comparison of liver weight of rats between groups $(n=33)$

\begin{tabular}{|c|c|c|}
\hline Groups & Liver weight (g) & $\mathrm{p}$ values \\
\hline $\mathrm{A}_{1}$ vs $\mathrm{A}_{2}$ & $\begin{array}{l}3.57 \pm 0.40 \text { and } 4.22 \pm 0.55 \\
(3.0-4.2)\end{array}$ & $0.007 * *$ \\
\hline $\mathrm{A}_{1}$ vs $\mathrm{B}$ & $\begin{array}{l}3.57 \pm 0.40 \text { and } 3.88 \pm 0.42 \\
(3.0-4.2)\end{array}$ & $0.453^{\mathrm{ns}}$ \\
\hline $\mathrm{A}_{2}$ vs $\mathrm{B}$ & $\begin{array}{l}4.22 \pm 0.55 \text { and } 3.88 \pm 0.42 \\
(3.3-5.0)\end{array}$ & $0.280^{\mathrm{ns}}$ \\
\hline
\end{tabular}

Results are expressed as mean \pm SD. Statistical analysis was done by ANOVA test and then by Bonferroni test to compare between two groups. Figures in parentheses indicate ranges.

Group $A_{1}$, baseline control group; Group $A_{2}$, Paracetamol-treated control group; Group B, Mushroom pretreated and paracetamoltreated group; ns, non-significant; ${ }^{* *}$, significant at $\mathrm{p}<0.01$ 


\section{Histological observation of liver in rats of different groups}

In Group $\mathrm{A}_{1}$ (baseline control group) hepatic structure was normal (Fig 1). In Group $A_{2}$ (paracetamol-treated group) moderate histological changes (presence of centrilobular necrosis, disorganization of hepatic sinusoids, infiltration of lymphocytes and Kupffer cells, fatty changes and ballooning degeneration) were found (Figs 2, 3 and 4). In Group B (mushroom pretreated and paracetamol-treated group) normal histological findings were observed in 8 rats (Fig 5), but presence of minimal fatty change, ballooning degeneration, infiltration of lymphocytes and centrilobular necrosis were found in 2 rats.

Table IIIA shows the distribution of rats by histological changes in liver. In this study, histological examination of liver revealed normal findings in $100 \%$ of rats in Group $A_{1}$ and abnormal histological findings were observed in $100 \%$ of rats in Group $A_{2}$. Eighty per cent of rats in Group B showed almost normal structure whereas $20 \%$ showed mild histological changes in liver. Though the percentage of abnormal histological changes was higher in Group B than that of Group $A_{1}$ but the difference was statistically non-significant. Table IIIB shows comparison of histological findings in liver.

Table IIIA: Distribution of rats by histological changes in liver $(\mathrm{n}=33)$

\begin{tabular}{|l|c|c|}
\multicolumn{1}{|c|}{ Groups } & \multicolumn{2}{|c|}{ Histological findings } \\
\hline & $\begin{array}{c}\text { Normal } \\
\text { Number }(\%)\end{array}$ & $\begin{array}{c}\text { Abnormal } \\
\text { Number }(\%)\end{array}$ \\
\hline Group A1 $(\mathrm{n}=10)$ & $10(100.0)$ & $0(0)$ \\
\hline Group A2 $(\mathrm{n}=13)$ & $0(0)$ & $13(100.0)$ \\
\hline Group B $(\mathrm{n}=10)$ & $8(80.0)$ & $2(20.0)$ \\
\hline
\end{tabular}

Table IIIB: Comparison of histological findings of liver between groups $(n=33)$

\begin{tabular}{|l|l|}
\hline Groups & p values \\
\hline $\mathrm{A}_{1}$ vs $\mathrm{A}_{2}$ & $0.001^{* * *}$ \\
$\mathrm{~A}_{1}$ vs B & $0.474^{\mathrm{ns}}$ \\
$\mathrm{A}_{2}$ vs B & $0.001^{* * *}$ \\
\hline
\end{tabular}

Statistical analysis was performed by Fisher's exact test

Group $A_{1}$, baseline control group; Group $A_{2}$, Paracetamoltreated control group; Group B, Mushroom-pretreated and paracetamol-treated group; ns, non-significant; ***, significant at $\mathrm{p}<0.001$

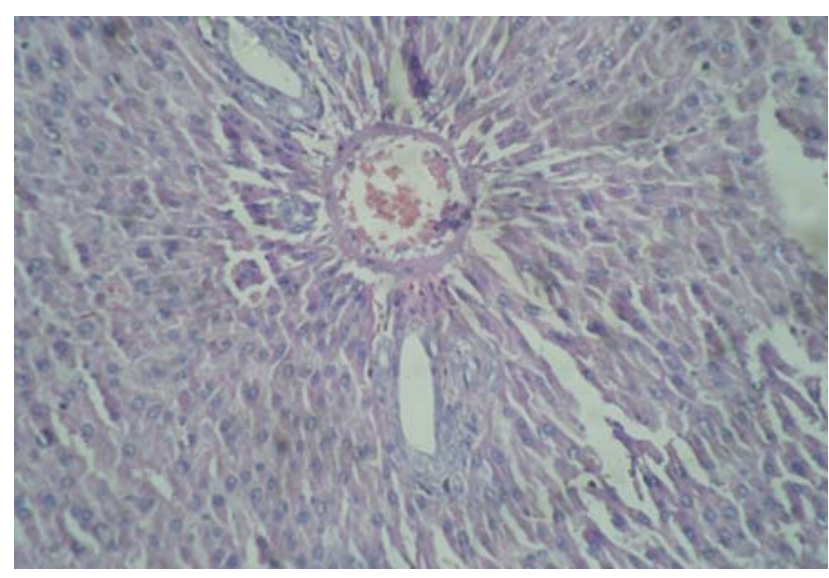

Fig 1. Photomicrograph showing architecture of liver of baseline control rats $(\times 400)$

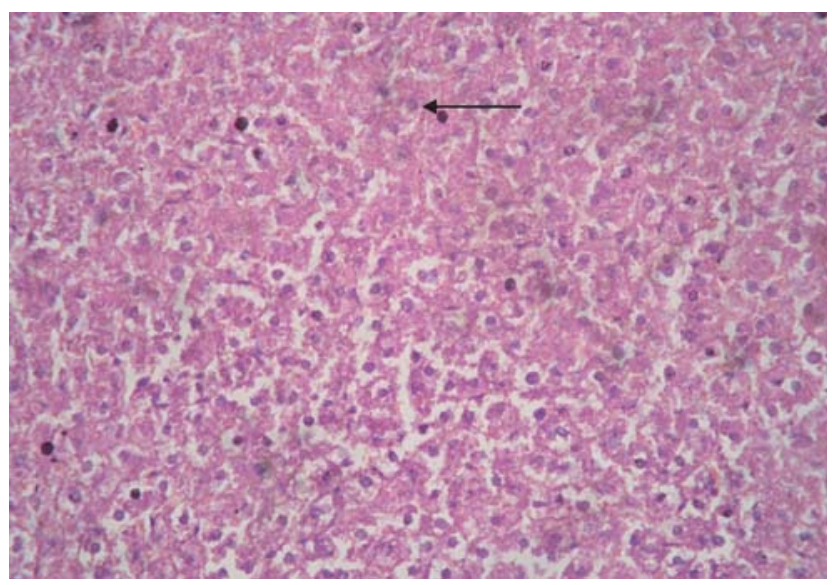

Fig 2. Photomicrograph showing centrilobular necrosis and ballooning degeneration (shown by arrow) of liver of paracetamol-treated control rats $(\times 400)$

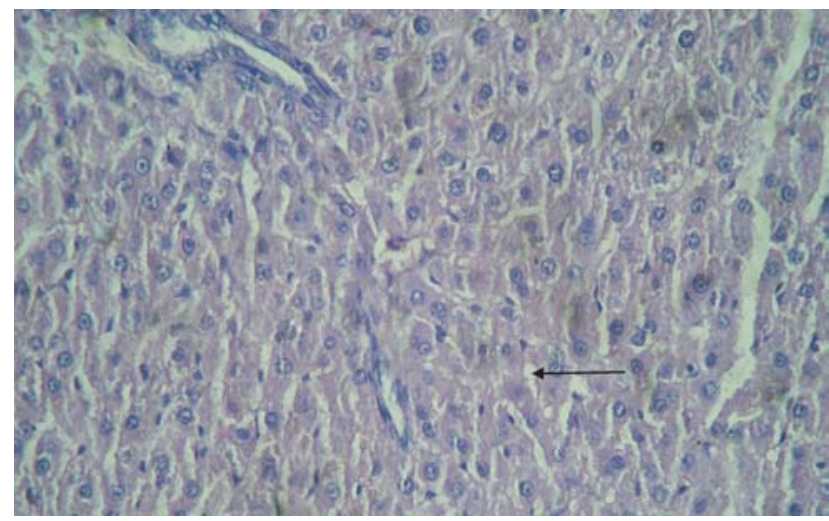

Fig 3. Photomicrograph showing centrilobular necrosis and fatty changes (shown by arrow) of liver of paracetamol-treated control rats $(\times 400)$ 


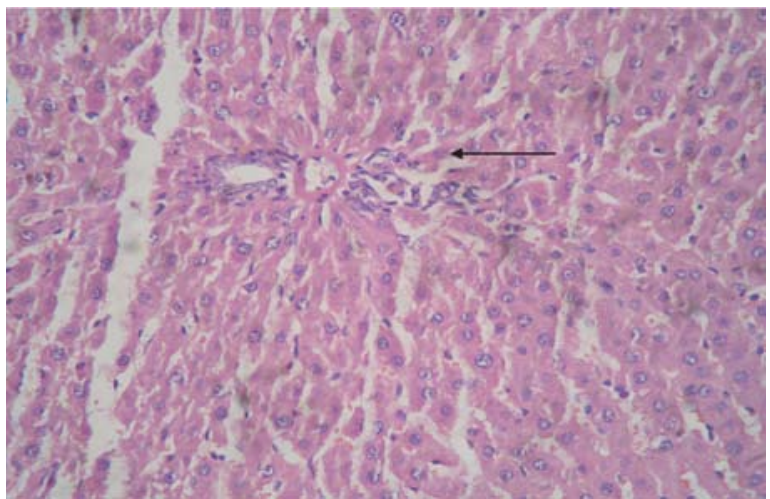

Fig 4. Photomicrograph of liver of paracetamol-treated control rats, arrow shows lymphocytic infiltration $(\times 400)$

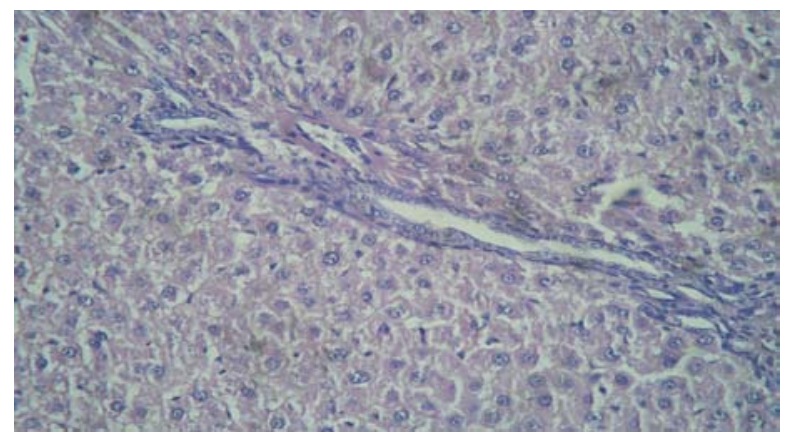

Fig 5. Normal histological findings in mushroompretreated and paracetamol-treated control rats $(\times 400)$

\section{Discussion}

In this study, the final body weight of all the animals were found increased compared to their initial weight, but this was statistically nonsignificant. This finding is in agreement with that of some other researchers. ${ }^{17}$ The percentage change of body weight from initial body weight to the final body weight was significantly lower $(\mathrm{p}<0.05)$ in mushroom-pretreated and paracetamoltreated group compared to that of baseline control group. This is similar to the findings of other investigators. ${ }^{18}$ The liver weight was significantly higher $(\mathrm{p}=0.007)$ in paracetamol-treated rats compared to that of baseline control group, but nonsignificantly higher when compared to that of mushroom-pretreated and paracetamol-treated group. Nonsignificant difference in this value was observed in mushroompretreated and paracetamol-treated rats in comparison to that of baseline control rats.

In this study, moderate histological changes such as centrilobular necrosis, disorganization of hepatic sinusoids, infiltration of lymphocytes and Kupffer cells, fatty changes and ballooning degeneration were observed in paracetamol-treated rats. These findings are also in agreement with those of different investigators of other countries. ${ }^{19,20}$ On the other hand, only minimal histological changes of liver were noted in $20 \%$ rats of mushroom-pretreated and paracetamol-treated rats which are in consistence with findings of different researchers of different countries. ${ }^{9,13}$

Extensive studies on the development of hepatic damage with paracetamol showed centrilobular necrosis in the liver including infiltration of lymphocytes and Kupffer cells, fatty changes and ballooning degeneration in overdose due to increased production of free radicals. ${ }^{15,19}$ Again, it has been suggested that, hepatotoxicity may be produced by altering liver microsomal membranes in experimental animals. ${ }^{21}$ The antioxidant activity or the inhibition of the generation of the free radicals is important in providing protection against hepatic damage. ${ }^{22}$ Many studies have been carried out to find out antioxidants of natural origin. Among the various naturally occurring substances, mushroom may be one of the effective antioxidants due to its free radical scavenging activity. ${ }^{23}$ Some research workers suggested that the possible antihepatotoxic mechanisms may be related to the suppression of tumor necrosis factor- $\alpha \alpha)$ and free radical scavenging activity. This anti-inflammatory role of mushroom may be helpful in protecting the hepatocyte from damage. ${ }^{12}$ Moreover, it has been suggested that the extract of mushroom probably acts to prevent the fall of glutathione (GSH) through some GSH dependent enzymes. Thus the structural integrity of the hepatic cell membrane is preserved. ${ }^{24}$

Different researchers suggested that some active compounds present in Oyster mushroom such as $\beta$ glucan ${ }^{17}$, phenol and vitamin $\mathrm{C}^{18}$ scavenge free radicals and thus play the role for antioxidant property of mushroom. These active components of Oyster mushroom increase the activities of some antioxidant enzymes such as catalase (CAT), superoxide dismutase (SOD) and glutathione peroxidase $\left(\mathrm{GP}_{\mathrm{x}}\right)^{17}$ and these antioxidant activities of mushroom cause reduction of hepatic cell necrosis ${ }^{12}$, stabilization of hepatic cell membrane ${ }^{13}$ and may protect the liver architecture by scavenging free radicals.

In the present study, hepatic damage was observed in rats treated with paracetamol as evidenced by moderate 
changes in liver architecture observed by histological examination. These changes may be due to increased production of free radicals which initiate lipid peroxidation and subsequent cell damage. 19,20

Histopathological changes found in mushroompretreated and paracetamol-treated groups were less than those of paracetamol-treated rats' liver. It provides a direct evidence of hepatoprotective effect of the extract of Oyster mushroom. However, the exact mechanism involved in the hepatoprotective activity of Oyster mushroom extract against paracetamol induced liver damage in rats cannot be found out from this type of study. According to the suggestions made by different investigators, free radical scavenging activities may be responsible for the effect. ${ }^{9,12,13}$

From this study it can be concluded that Oyster mushroom (Pleurotus florida) may have some hepatoprotective role, but the active component of mushroom, which is responsible for this effect, is not known. The hepatoprotective effect may be due to its free radical scavenging activity.

\section{Acknowledgement}

We are thankful to the authority of National Mushroom Development and Extension Centre, Savar, Dhaka for the cooperation regarding mushroom supply and also to department of Biochemistry and Molecular Biology and department of Pharmacy of Jahangirnagar University for the laboratory support they provided. We also acknowledge the department of Pathology of Sir Salimullah Medical College, Mitford, Dhaka for their help to prepare the slides.

\section{References}

1. Digestion. In: Keele CA, Neil E, Joels N (eds). Samson Wright's applied physiology. 13th edn. New Delhi: Oxford University Press, 1982: 422-444.

2. Hwang JM, Tseng TH, Tsai YY, Lee HJ, Chou FP, Wang CJ et al. Protective effects of baicalein on tert-butyl hydroperoxide-induced hepatic toxicity in rat hepatocytes. Journal of Biomedical Science 2005; 12: 389-397.

3. Dahlin DC, Miwa GT, Lu AYH, Nelson SD. N-acetyl-pbenzoquinone-imine: a cytochrome P-450 mediated oxidation product of acetaminophen. Proc Natl Acad Sci USA 1984; 81: 1327-1331.

4. James LP, Mayeux PR, Hinson JA. Acetaminophen-induced hepatotoxicity. Drug Met Disp 2003; 31: 1499-1506.

5. Michael SL, Pumford NR, Mayeux PR, Niesman MR, Hinson JA. Pretreatment of mice with macrophage inactivators decreases acetaminophen hepatotoxicity and formation of reactive oxygen and nitrogen species. Hepatology 1999; 30: 186-195.

6. Hinson JA, Bucci AR, Irwin LK, Michael SL, Mayeux PR. Effects of inhibitors of nitric oxide synthase on acetaminophen induced hepatotoxicity in mice. Nitric Oxide: Biology and Chemistry 2002; 6: 160-167.

7. Koyama T, Chounan R, Uemura D, Yamaguchi K, Yazawa K. Hepatoprotective effect of a hot water extract from the edible thorny oyster Spondylus varius on carbon tetrachloride induced liver injury in mice. Biosci Biotechnol Biochem 2006; 70(3): 729-731.

8. Çaðlarirmak N. The nutrients of exotic mushrooms (Lentinula edodes and Pleurotus species) and an estimated approach to the volatile compounds. Food Chem 2007; 105: 1188-1194.

9. Jayakumar T, Ramesh E, Geraldine P. Antioxidant activity of the Oyster mushroom Pleurotus osteratus, on CCL4 induced liver injury in rats. Food and Chemical Toxicology 2006; 44: 1989-1996.

10. Selvi S, Arunavadas, Umadevi P. Hepatoprotective effect of the ethanolic extract of Pleurotus florida and Calocybe indica against CCL4 induced hepatic damage in albino rats. The Icfai University Journal of Life Sciences 2008; 2(4): 17-28.

11. Lin MJ, Lin CC, Chen MF, Ujiie T, Takada A. Radical scavenger and antihepatotoxic activity of Ganoderma formosanum, Ganoderma lucidum and Ganoderma neojaponicum. J of Ethnopharmacology 1995; 47: 33-41.

12. Yang XJ, Liu J, Ye LB, Yang F, Ye L, Gao JR et al. In vitro and in vivo protective effects of proteoglycan isolated from mycelia of Ganoderma lucidum on carbon tetrachloride induced liver injury. World J Gastroenterol 2006; 12(9): 1379-1385.

13. Shi Y, Sun J, He H, Guo H, Zhang S. Hepatoprotective effects of Ganoderma lucidum peptides against Dgalactosamine-induced liver injury in mice. $\mathrm{J}$ of Ethnopharmacology 2008; 117: 415-419.

14. Ooi VEC. Hepatoprotective effect of some edible mushrooms. Phytother. Res. 1996; 10: 536-538.

15. Mandal SC, Saraswathi B, Kumar CKA, Lakshmi SM, Maiti BC. Protective effect of leaf extract of Ficus hispida Linn. against paracetamol-induced hepatotoxicity in rats. Phytother Res 2000; 14(6): 457-459.

16. Sweetman SC. The complete drug reference. $33^{\text {rd }}$ edn. Great Britain. The Pharmaceutical Press, 2002.

17. Bovek P, Ozdin L, Kuniak L. Effect of Oyster mushroom and isolated $\beta$-glucan on lipid peroxidation and on the activities of antioxidative enzymes in rats fed the cholesterol diet. The Journal of Nutritional Biochemistry 1997; 8: 469-471. 
18. Fu HY, Shieh DE, Ho CT. Antioxidant and free radical scavenging activities of edible mushrooms. J Food Lipids 2002; 9: 35-43.

19. Mroueh M, Saab Y, Rizkallah R. Hepatoprotective activity of Centaurium erythraea on acetaminophen induced hepatotoxicity in rats. Phytother. Res. 2004; 18: 431-433.

20. Rajkapoor B, Venugopal Y, Anbu J, Harikrishnan N, Gobinath M, Ravichandran V. Protective effect of Phyllanthus polyphyllus on acetaminophen induced hepatotoxicity in rats. Pak J Pharm Sci 2008; 21(1): 57-62.

21. Hiroshi A, Toshiharu H, Masahoro H, Shoji A. An alteration in liver microsomal membranes of rat following paracetamol overdose. J Pharm Pharmacol 1987; 39: 1047-1049.

22. Handa SS, Sharma A, Chakraborty KK. Natural products and plants as liver protecting drugs. Firoterapia 1989; 57: 307.

23. Jose N, Janardhanan KK. Antioxidant and antitumour activity of Pleurotus florida. Curr Sci 2000; 79(7): 941-943.

24. Vermeulen NPE, Bessems JGM, Straat VD. Molecular aspects of paracetamol-induced hepatotoxicity and its mechanism-based prevention. Drug Metabolism Reviews 1992; 24(3): 367-407. 